DOI: https://doi.org/10.11144/Javeriana.upsy18-3.wvwe

\title{
Workplace Violence in Work Environments against Gender Violence*
}

\section{Violencia laboral en contextos donde se trabaja contra la violencia de} género

Received: 01 August 2018 | Accepted: 25 July 2019

\author{
Alicia Pérez-Tarrés a \\ Universitat Autònoma de Barcelona, Spain \\ ORCID: http://orcid.org/0000-0002-3686-1430 \\ Joilson Pereira da Silva \\ Universidade Federal de Sergipe, Brazil \\ ORCID: http://orcid.org/0000-0001-9149-3020 \\ Leonor María Cantera Espinosa \\ Universitat Autònoma de Barcelona, Spain \\ ORCID: http://orcid.org/0000-0002-4541-5993
}

a Correspondence author. Email: ptt.alicia@gmail.com

How to cite: Pérez-Tarrés, A., Pereira da Silva, J., \& Cantera-Espinosa, L. M. (2019). Workplace Violence in Work Environments against Gender Violence, Universitas Psychologica, 18(3), 1-15. https:// doi.org/ 10.11144/Javeriana.upsy18-3.wvwe

\begin{abstract}
We aimed to describe and analyze the subjective experiences concerning workplace violence in a group of 20 workers. The scenario chosen shows a paradoxical situation: violence in environments where people work against gender violence. A qualitative method was used and the instrument chosen was the semi-structured interview. The results indicate a reproduction of violence within these work contexts, which manifests itself mainly in a psychological way and whose causes are subject to social, institutional and personal variables. From this research, several notable theoretical and methodological phenomena emerge, as well as the need for profound reflections based on the academic approaches to workplace violence.

Keywords

Workplace violence; gender violence; reproduction of violence; personal factors.
\end{abstract}

\section{RESUMEN}

El objetivo del presente trabajo fue describir y analizar las experiencias subjetivas relacionadas con la violencia en el lugar de trabajo, en un grupo de 20 trabajadores. El escenario elegido muestra una situación paradójica: ambientes violentos donde las personas trabajan contra la violencia de género. Se utilizó un método cualitativo y el instrumento elegido fue una entrevista semiestructurada. Los resultados indican una reproducción de la violencia en este ámbito laboral, que se manifiesta psicológicamente, y cuyas causas están sujetas a variables sociales, institucionales y personales. A partir de esta investigación, emergen varios fenómenos teóricos y metodológicos notables, así como una necesidad de reflexión profunda basada en aproximaciones académicas a la violencia en el lugar de trabajo. Palabras clave

violencia en el lugar de trabajo; violencia de género; reproducción de la violencia; factores personales. 
Talking about violence means referring to a multifaceted concept that is strongly present in the history of humanity. Many conflicts, transcending themselves, have turned into violence and have led people to absolute dehumanization (Ansoleaga, Díaz, Mauro, \& Toro, 2017). Violence, socially understood as a problem and solution in very diverse cases, is used at many levels as a strategy to maintain power or achieve a proposed goal. It accommodates such a broad spectrum of behaviors and actions that the boundary between what is acceptable and what is not is often very vague, so the perception of what constitutes violence varies across different contexts and cultures (Ansoleaga et al., 2017). Knowing this scenario, it is not obvious to ask: What is violence? What causes it? What motivates it? In what contexts does it occur? Who executes it?

Violence is understood as "any action or intentional conduct that causes or may cause harm" (Sanmartín, 2007, p. 3). It is defined as a harmful action (or inaction, i.e. omission) (Sanmartín, 2012), which can be both physical and symbolic and is of a hostile nature (Cantera, 2004). Violence occurs not only at the micro, personal, intimate, but also at the macro, structural, global level.

Some authors have proposed models to explain the causes and cycles of violence. For example, in 2013, Cantera, Pallarès, and Selva affirm that violence takes place within a fundamentally patriarchal context. According to Cantera $(1999,2004)$, "patriarchy, like any other type of sociocultural system, sets the rules of the game of conceivable, permissible and enforceable violence" (p. 32). Likewise, this author proposes a model to discern the context where the violence is located, assuming in the first instance that it is a permitted and legitimized resource and a control tool; which guarantees whoever exercises it the perpetuation of his/her superior position; and, finally, which reinforces the feeling of power, control, domination and status.

One of the contexts where violence and its manifestations have been widely studied, among many others (school, gender, youth, wars, etc.), are the work environments. According to Topa, Depolo, and Morales (2007) there is still no consensus definition of workplace mobbing or harassment, but it can be understood as a process of systematic and repeated aggression by a particular group or individual towards a subordinate, a superior or a co-worker of the same rank in a work environment. Granting a broader sense to the concept of mobbing, workplace violence can be defined as "any action, incident or behavior that departs from reasonable conduct in which a person is assaulted, threatened, harmed, injured in the course of, or as a direct result of, his or her work" (ILO, 2003, p.4). This definition catalyzes the inclusion of different violent actions, ranging from physical or psychological violence to subtle forms such as psychological or sexual harassment or incivility (Toro \& Gómez-Rubio, 2016).

According to the California Division of Occupational Health and Safety (Cal/OSHA), workplace violence could be classified according to the following types: Type I, caused by external agents without a legitimate link with the victim; Type II, caused by users, customers, patients, consumers; Type III, caused by colleagues, subordinates or heads (1995).

Considering the range of the definition, the variety of behaviors or conducts that can be manifested and the number of agents involved, estimating the magnitude of this problem is not easy. In their investigations, most studies delimit their work by the definition of moral harassment or mobbing, sexual harassment or physical violence. Thus, other violent behaviors that occur in work settings and the socioeconomic context itself are not fully contemplated according to Toro and Gómez-Rubio (2016, p. 115).

Violence should be considered as a systemic problem, involving micro and macro social aspects, daily relationships, but also the structure of the job market and resulting forms of work organization, which impose an increasingly precarious system of job conditions and relationships.

In addition, some investigations provide information on the scope of this problem. 
The prevalence of psychological harassment by economic sectors reported in the third survey on working conditions in Europe in 2000 was: finance $(5 \%)$, health and education (12\%) and transport and telecommunications (12\%). The percentage of sexual harassment would be superior to one (2\%), as well as physical violence (2\%). In the Spanish context, the VI National Survey of Working Conditions in Spain (Ministry of Labor and Social Affairs, 2007) affirms prevalence rates ranging between 1.4\% and $2.9 \%$, depending on the use of a more or less restrictive measuring criterion.

In a meta-analysis on workplace violence by Topa et al. (2007), several causal models are exposed that can serve as reliable predictors of harassment at work. The first of these models is related to the personal (demographic and personality) characteristics of the harassed. The second is related to the contextual and organizational characteristics of these work environments.

Numerous studies raise conclusions that could be framed within these two models. Next, some of them are presented. In relation to the personality and characteristics of the harassed workers, the intensity of the violence is related to belonging to the female gender; being widowed, divorced or separated, working accumulated workdays, rotating shifts and being exposed to negative psychosocial factors in the job (Pando, Aranda, Salazar, \& Torres, 2016). Also, characteristics such as low self-esteem, obsessive-compulsive behaviors and a significant demand for attention have been highlighted in a systematic review by Parra and Acosta in 2010 as personal characteristics of the people harassed. Regarding these workers' attitudes and coping strategies, according to Toro and Gómez-Rubio (2016), in a study conducted in Brazil by Acosta, Aguilera, and Pozos (2009), it is affirmed that personal styles that combine domination (of the victimizer) and avoidance (by the victim) constitute a risk factor for workplace harassment. According to Baillien et al. (2009), in their qualitative study on the development of bullying in the workplace, it was affirmed that bullying started with inefficiency to face frustrations (tensions) in an active or passive way.

For the second model (contextual and organizational characteristics) presented in the meta-analysis by Topa et al. (2007), the variables would relate to an aggressive economic environment, technological development and a new valuation of human capital (Pando et al., 2016). The climate of goals, organizational change, labor inequity, the type of hiring, role conflict and task burden have been presented as organizational factors that give rise to workplace harassment (Parra \& Acosta, 2010). Some studies support the hypothesis that very hierarchical, undemocratic organizations with values of competitiveness would be antecedents of harassment at work (Topa et al., 2007). The climate of support, norms, the level of selfesteem at work or satisfaction in relationships with superiors are also factors that could predict workplace violence (Parra \& Acosta, 2010). Finally, in a qualitative study carried out through semi-structured interviews (López $\&$ Seco, 2016), it was argued that workplace harassment could also occur as a result of a conflict of interest regarding labor rights (health in the workplace, motherhood or union participation).

Therefore, the practice of violence in a work environment (intended context for this study) has particularities that can behave as facilitators of these behaviors, which interact with the personal characteristics of those who exercise or receive violence and with characteristics of the socio-occupational environment they are located in. This violence threatens the physical and psychological integrity of the workers, causing severe consequences for their physical and mental health. These consequences include stress, mild and moderate forms of anxiety, depression, sleep disorders (Román, 2017), difficulties in interpersonal relationships with family, peers and friends (Parra \& Acosta, 2010), headaches, neck pain, back pain, stomach ache, hypertension, memory alterations based on attention deficit and insomnia (Pastrana, 2002).

Occasionally, the characteristics of the work will significantly affect the problems and 
repercussions suffered by professionals. This is the case of those who work with situations of violence in all of its manifestations. The discomfort the workers and teams involved in the treatment of violence situations experience has been conceptualized based on different terms: burnout, vicarious traumatization or compassion fatigue (Arón \& Llanos, 2004; Acinas, 2012). According to a study by Arón and Llanos (2004), being exposed to a high degree of professional burnout can be the cause of severe psychological disorders, abandonment of the profession or the field of work. In addition to the physical, psychological and behavioral repercussions these professionals are victims of, it is worth mentioning the destructive dynamics that are generated within these teams, as a consequence of the lack of models to explain the difficulties they experience (Bernad, Pérez, Díaz, García, \& Villagrasa, 2013).As a result of these dynamics, not only can the violence that is combated be reproduced in the work centers with the co-workers. In addition, relations of submission and subordination with the service users (that is, people attended) can be reproduced (Cantera \& Cantera, 2014).

Due to the multifaceted, macro and structural nature that defines gender violence, actions to prevent and investigate it have been produced in different disciplines (justice, education, social work, psychology) and in a planned and coordinated manner. Particularly in Spain, the intervention has been organized and designed for interdisciplinary work teams from public entities, but also from associations and private entities. There are many needs and advantages that justify this approach of the problem, although some professionals alert on the difficulties involved in working with emotionally stressful workfrom different theoretical frameworks.

In recent decades, the scientific and academic community and a wide range of national (Spanish context) and international organizations have tried to study and visualize the violence that occurs in the workplace. These studies, with different approaches and designs, show different scenarios in which violence remains constant. Therefore, despite all the actions taken and despite a further understanding of the phenomenon, violence continues to emerge without being able to control the variables that make it possible. Most studies analyzed in this field intend to describe, quantify and measure the phenomenon, leaving aside the meaning the people involved attribute to it. Likewise, a large number of published studies emphasize the individual characteristics of bullies and victims in their relationship, but few take interest in the contextual or organizational characteristics that make it possible for violence to emerge. The aforementioned situations evidence the need to move into the research field, aiming to discover the underlying concepts, so as to gain an in-depth understanding of the meaning people assign to the violence they practice or receive in the environments they participate in.

The general objective of this research is to identify and analyze the subjective, relational and organizational components involved in the production of workplace violence, as well as its characteristics in environments where work is being done to eradicate gender violence.

This general objective translates into two specific objectives:

Identify, describe and analyze the contextual, social, personal and institutional variables that affect the emergence and maintenance of violence in environments where work is being done to eradicate gender violence.

Identify, describe and analyze the characteristics of the violence suffered in environments where work is being done to eradicate it.

This investigation will consider workplace violence in its broadest definition, assuming that it goes beyond workplace or sexual harassment or the physical violence that may occur in a work environment. We want to clarify this theoretical starting point, as it seems important to investigate what López and Seco have already pointed out in 2016 when they affirm in their study that the concept of mobbing needs to be deconstructed, detached from the interpersonal emphasis that leads to the obscurity of the corporate responsibility. To the latter, we also 
want to add political and social responsibility for these practices.

\section{Method}

\section{Design}

It is a qualitative, descriptive and exploratory study. This type of research promotes observation and interpretation through the inductive method, aiming to discover new concepts from a holistic perspective (Quintana, 2006). The study was developed based on information obtained in in-depth semistructured interviews with professionals and paraprofessionals working in public and private associations against gender violence. The in-depth interview is the most appropriate technique to respond to our research objectives as it allows us to access each participant's subjective universe, trying to discover in each case the uniqueness of these experiences without being influenced in advance by the generic and established theories (Quintana, 2006).

The research design had flexible and emerging characteristics, aiming for an objective and systematized study, but following the logic of a qualitative design that, as Quintana pointed out in 2006, consists of working around four basic characteristics: openness, flexibility, strategic sensitivity and referentiality or nonprescriptiveness. Finally, to guarantee the quality of the study, the recommendations of the Consolidated Criteria for Reporting Qualitative Research (COREQ) were followed.

\section{Sample and context}

An intentional sample was selected in this research. This means choosing selectively those participants who guarantee the quantity (saturation or state in which there is no new information on a topic) and the quality (wealth) of the information (Relinque, Moral, \& González, 2013). In addition, the intentional selection strategy also helps us to ensure typical cases, in order to highlight what is normal or average for the chosen group (Morrow \& Smith, 2000). The selection of the participants was carried out by means of snowball sampling, which consists of finding a case belonging to the group that is to be investigated and this one leads to the next and so on, until reaching a sufficient level of information to close off the participant selection phase (Quintana, 2006).

Thus, the sample consisted of 18 women and 2 men from the province of Barcelona-Spain. As mentioned, to select the participants, the snowball sampling technique was used with the following inclusion criteria:

a) Possessing training in violence

b) Working currently against gender violence

c) Having worked in the past against gender violence

The elected workers correspond to a social / welfare area in the province of BarcelonaSpain (it is noteworthy that these sectors have been deeply punished by the economic crisis in recent years in the European-Spanish context, leading to great insecurity in the job market). They are professionally engaged in actions related to research, prevention, intervention and eradication, direct or indirectly, in the field of gender violence. These workers come from different fields or disciplines: Advocacy, social education, psychology and social work. They work at public institutions (town councils) or in private entities / associations. These variables, together with the inclusion criteria, provided the ideal worker profile for the research phenomena.

Table 1 shows a summary of the study participants' main socio-demographic characteristics. The names that appear in the table are pseudonyms. Fictitious names were granted for the sake of research ethics, as well as to safeguard the participants' identity. 
Table 1

Sociodemographic data

\begin{tabular}{|c|c|c|c|c|c|c|}
\hline Participant & Age & Sex & Children & $\begin{array}{c}\text { Marital } \\
\text { status }\end{array}$ & Function & $\begin{array}{c}\begin{array}{c}\text { Type of } \\
\text { institution }\end{array} \\
\end{array}$ \\
\hline Inés (5) & 36 & Woman & One daughter & Divorced & Center coordinator & Public \\
\hline Helena (10) & 52 & Woman & Two sons & Married & Social educator & Public \\
\hline Raquel (9) & 40 & Woman & No & Single & $\begin{array}{l}\text { Coordinator of gender } \\
\text { equality programs }\end{array}$ & Public \\
\hline Amanda (8) & 59 & Woman & Two sons & Married & Social worker & Public \\
\hline Aida (7) & 38 & Woman & No & Married & Psychologist & Public \\
\hline Malena (4) & 54 & Woman & Two sons & Married & College professor & Private \\
\hline Núria (6) & 47 & Woman & $\begin{array}{l}\text { One daughter } \\
\text { and one son }\end{array}$ & Married & Psychologist & Public \\
\hline Miriam (2) & 77 & Woman & $\begin{array}{l}\text { Two sons and } \\
\text { one daughter }\end{array}$ & Divorced & $\begin{array}{l}\text { Coordinator women's } \\
\text { association }\end{array}$ & Private \\
\hline Jordi (3) & 43 & Man & $\begin{array}{l}\text { One daughter } \\
\text { and one son }\end{array}$ & Married & Private psychologist & Private \\
\hline Lidia (1) & 44 & Woman & $\begin{array}{c}\text { Two } \\
\text { daughters }\end{array}$ & Married & Psychologist & Public \\
\hline Cristina (11) & 27 & Woman & No & Single & $\begin{array}{l}\text { Psychologist women's } \\
\text { association }\end{array}$ & Private \\
\hline Susana (12) & 56 & Woman & One daughter & Married & Social educator & Public \\
\hline Pilar(13) & 53 & Woman & One son & Married & Equality technician & Public \\
\hline Sonia (14) & 52 & Woman & One son & Married & Psychologist & Public \\
\hline Noemi (15) & 27 & Woman & No & Single & $\begin{array}{l}\text { Psychologist at } \\
\text { association }\end{array}$ & Private \\
\hline Carlos (16) & 28 & Man & No & Single & $\begin{array}{l}\text { Psychologist at social } \\
\text { entity }\end{array}$ & Public \\
\hline Diana (17) & 46 & Woman & No & Single & $\begin{array}{l}\text { Legal advisor and } \\
\text { lawyer }\end{array}$ & Public \\
\hline Ana (18) & 43 & Woman & One son & Married & $\begin{array}{l}\text { Center coordinator and } \\
\text { social educator }\end{array}$ & Private \\
\hline Lucía (19) & 38 & Woman & One daughter & Married & Legal advisor & Public \\
\hline Lourdes (20) & 36 & Woman & No & Married & $\begin{array}{l}\text { Psychologist in } \\
\text { women's care }\end{array}$ & Public \\
\hline
\end{tabular}

The instrument used in this investigation was the in-depth interview. This technique aims to know the perspective a subject has on his own life, the situations he lives or his experiences (Campoy \& Gomes, 2015). The researchers designed the interview to respond to the research objectives. Its design was carried out after an exhaustive literature search for concepts relevant for this study, including a review, reflection and consensus on the topics among the different researchers. These concepts were chosen taking into account the current scientific evidence on the research phenomena.

The interviews were semi-structured and organized according to three main areas: a) Work trajectory b) Violence and work c) Assertions about violence. These areas were explored through 29 open questions, introducing clarifying questions when appropriate. In addition, using a small questionnaire created ad hoc, information was collected on the following sociodemographic characteristics: name, sex, age, marital status, circle of coexistence and children. Finally, field notes were collected during all the interviews with related information (description and non-verbal language of the participants), and recording of key information and incidents during the interview. The interviews were held in
Spanish, face to face and lasted between 40 and 60 minutes.

\section{Data collection and analysis strategies}

Once the contacts with the participants had been established, following the aforementioned methods, the interviews were held. These were carried out over a five-month period, at the participant's convenience.

The interviews were carried out in different spaces, requiring only a calm and quiet place for the researcher to avoid interference in the interviews and recordings, but always at the participant's request, with a view to ensuring their access to the study. All interviews were audio-recorded using a simple recorder. Likewise, the interviewer orally collected the sociodemographic information, filling out a short questionnaire in situ. All participants were informed about the confidentiality and other ethical aspects of the research, and also about the return of the results obtained. At the beginning and during the interviews, the interviewer tried to establish a climate of trust with the interviewee, increasing the intensity and intimacy of the questions as appropriate relational rapport was established. Participants were recruited until the theoretical saturation of the data was reached (i.e. when admitting new participants did not add anything new to the concept of study (Strauss \& Corbin, 1998). The interviews were fully transcribed using the software InqScribe.

The transcripts of the interviews were examined according to the Grounded Theory. Among the theoretical bases of this theory, we point out symbolic interactionism, which tries to develop interpretations of the subjects' world in function of their own interpretations, with human action as an object of investigation (San Martín, 2014). Likewise, and following the procedures of the Grounded Theory, the information reported in the interviews was subject to open, axial and selective coding. Finally, the information was organized 
into dimensions, categories, subcategories and elements of analysis.

To enhance the reliability of the analysis, an intra-methodological methodological triangulation was used, which supposes the use of a methodological strategy the researcher applies at different moments in time (Aguilar \& Barroso, 2015). The transcriptions were reread several times in order to understand and capture the participants' experience through their discourse.

\section{Ethical considerations}

In all cases, informed consent was requested from the participants for inclusion in the study. They were informed of the method used, as well as the objectives set out in the investigation. The informed consent included the following information: method, objectives, dissemination and phases. Information was also provided on their anonymity and the confidentiality of the information they could report. Their right to drop out of the study when they considered it appropriate was specified. Finally, it was specified that there are no conflicts of interest in this research.

\section{Results}

After the development of the fieldwork and the qualitative data analysis detailed earlier, the dimension workplace violence was obtained, which consisted of three categories and eleven subcategories (see Table 2).

\section{Table 2}

Dimension, categories and subcategories coded in the study

\begin{tabular}{ccc}
\hline Dimension & Categories & Subcategories \\
\hline & $\begin{array}{c}\text { Difficulties related to the work } \\
\text { against gender violence }\end{array}$ & $\begin{array}{c}\text { Social or contextual factors } \\
\text { Personal factors } \\
\text { Institutional factors }\end{array}$ \\
\cline { 2 - 3 } $\begin{array}{c}\text { Workplace } \\
\text { violence }\end{array}$ & Job conflicts & $\begin{array}{c}\text { Conflicts with users } \\
\text { Conflicts with co-workers } \\
\text { Conflicts with heads } \\
\text { Conflicts with the institution }\end{array}$ \\
\cline { 2 - 3 } & Characteristics of the violence & $\begin{array}{c}\text { Physical abuse } \\
\text { Psychological abuse } \\
\text { Role regarding violence } \\
\text { Cycle of violence }\end{array}$ \\
\hline
\end{tabular}

| Universitas Psychologica | V. I8 | No.3 | 2019 |
This classification permitted the systematic and rigorous identification, ordering and analysis of the information extracted. Likewise and to respond to the objectives, the experience of violence was analyzed through the categories detailed below: a) Difficulties related to working against gender violence, this category refers to the problems the participants encounter in their professional practice and is related with the social or contextual characteristics of the work in this area or with the personality and personal history concerning the professional work. b) Job conflicts, this category is defined as the problems that arise between the worker and other actors or agents whom he relates with in his work practice. c) Characteristics of the violence, refers to the attributes the participants have been able to assign to the type of violence they have seen or suffered in their jobs.

a) Difficulties related to working against gender violence

For the first category mentioned, participants mainly highlight social or contextual, personal and institutional factors as descriptors of the difficulties they experience. The social or contextual factors mentioned are the lack of social recognition, the worker's lack of legal protection and the female gender. In addition, the interviewed workers highlight struggles for power or struggles for resources available in the job market. The words of Aida (all names are fictitious) are an example of these elements, when she says that she is not sure that the violence has to do with a personal issue and rather relates it to the work teams:

I am not sure that the subject is what people are like, there is a theme related to the teams ... within the teams ... what I have seen are very human things ... the struggle for power, for recognition, for having a better position ... ( p.4)

The female gender element is included in this category given the job difficulties women encounter in belonging to a fundamentally patriarchal society. Paradoxically, these workers who struggle to change these frameworks suffer their consequences. In this fragment, Raquel 
shares her view on the incorporation of women in the job market: "What we have done is to add tasks because the structure has not adapted to this change, women suffer the double workday, the double presence ..." (p.10.)

The second subcategory, personal factors, is related to the personal characteristics of those who work to eradicate gender violence. Participants highlight the type of personality of those who practice violence (narcissistic and perverse), a personal history of violence not assumed or treated, lack of training for work to eradicate gender violence, negative feelings transferred to others and inappropriate emotional management.

Raquel explains how, according to her point of view, professionalization is not enough not to reproduce violent attitudes: "A person gets more professional, but if he does not do a powerful personal job and does not have a powerful education, he reproduces violence because it is what he has known..." (p.5). Or Ines, who explained the importance of having a personal position towards the violence, beyond the theory:

"That you have training does not guarantee anything ... because, fuck, you have learned in a context, and unlearning according to which strategies requires a personal review and surely, even if you are involved personally and have training, sometimes something escapes you ... " (p. 4)

The professionals who work in this sector have training and information about how violence behaves (specifically gender violence) and, in addition, they work and are committed to eradicating it. Precisely for this reason, the interviewees attribute great value to this subcategory, which was cited by all the interviewees in some of its dimensions.

Finally comes the third subcategory, institutional factors. The participants affirm that the shortage of resources, the job insecurity and institutional authoritarianism make their professional practice difficult. The comments presented below are a sample of their impressions when they comment on the difficulties they encounter in relation to the institution or the work context: "There are low salaries with emotionally very stressful jobs ... the teams have a lot of mobility because there is no recognition part, there is no part of good working conditions ... "(Aida, pg.7) or Malena:"Many times the cake is small and you have to distribute it among several ..." (p. 10). More specifically, the scarcity of resources refers to the lack of material and human resources to do the work well.

Precarious work involves low salaries, unpaid overtime and temporary contracts. Finally, institutional authoritarianism is related to a strict and much hierarchized attitude of the organization.

\section{b) Job conflicts}

This category is composed of four subcategories. For the first, conflicts with co-workers, the participants highlighted the following elements: discussions, triangulation, competitiveness and difference in theoretical frameworks. For example, Inés recounts the feelings that arose in a discussion with a partner, "That aroused discussion that, they hurt, they hurt because it's like ... host ... you do not give me any technical argument from violence to justify this approach ..." (p. 7), or Helena who also refers to conflicts with peers due to differences in the criteria: "If there are inequalities of criteria, this could lead to conflicts with peers" (p. 3). A more severe case would constitute the report by Raquel, in which she affirms that, as a result of the competitiveness between her and her coworkers, she ended up losing her job: "Then there is the competition among us ... they took my place directly" (p. 9).

In the following subcategory, conflicts with users, the demand or over-accountability of the professional as generators of problems has been highlighted. Conflicts with heads would be the third subcategory, which the interviewees defined through variables such as authoritarianism, invasion of intimacy in the workplace or abuse of power. Jordi, in the following fragment, narrates the attitude of his superior as authoritarian and relates it to countless conflicts: "The director, who exercised a very aggressive, very punitive, very old mandate, in the sense that I am in charge 
here and you are to obey, this generated a lot of discomfort and problems" (p. 5) or about the abuse of power: "The director felt beyond good and evil "(p.7).

The last category is related to the conflicts between the worker and the institution, which contains the following elements: political changes, lack of economic transparency, dismissal and changes in working conditions. In this respect, Jordi comments:

"One thing that has to do with service to others and turns into a company that wants more, more power and more ... this ambition is sometimes difficult to fit" (p.4), or Raquel: "I haven't stuck out my neck politically and they asked me to do so, that is also heavy, and from that moment on they did pim, pam ... you do not stick your neck out, we do not stick our neck out" (p. 6).

We found a strong relationship between these two categories, their subcategories and the workplace violence that is generated in this care setting. Figure 1 shows a conceptual map the authors created, in which these categories, subcategories and their elements of analysis are related.

\section{Figure 1}

Relation between the categories difficulties related to working with gender violence and job conflicts.

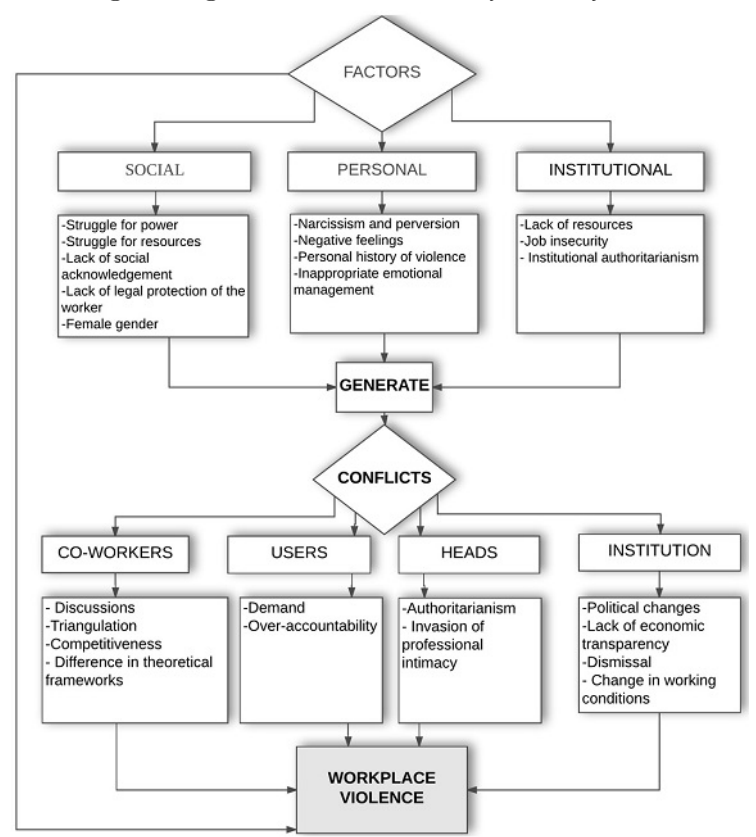

The analysis of the information reported by the interviewees shows the relationship between the violence that occurs and the conflicts that are generated within the organization. Likewise, the participants also highlight a type of violence that is not related to the conflict, but to personal characteristics of the people who generate violence. Therefore, our results indicate that the beginning of a violent action or attitude does always involve a conflict between two sides. Another very significant aspect to note is that the participants in better job conditions (good salary, open-ended contract, fixed conditions, etc.) report less violent experiences in their workplace.

\section{c) Characteristics of the violence}

This category consists of four subcategories: physical abuse, psychological abuse, cycle of violence and role with respect to violence. The participants' comments in these subcategories are displayed in Table 3.

The participants claimed to have suffered mainly psychological violence in their workplace. This type of violence would be framed in 
the subcategory of psychological abuse. The elements the participants commonly cited were: Insulting, ignoring, questioning, not recognizing, blackmailing, controlling, threatening, distorting and misusing. It should be noted that there was also physical violence, which two of the participants manifested. This violent action would fit into the subcategory physical abuse. These two subcategories (physical abuse and psychological abuse) would correspond to the manifestations the interviewees recognize concerning the violence they are victims of. Two of the interviewees in this study do not recognize having suffered any type of violence in their workplace.

Participants also characterize violence by manifesting the patterns it follows or who commits it. The interviewees can recognize the so-called "cycle of violence" in the situations they have seen or experienced in their jobs. Likewise, they acknowledge that they have been victims of violence and have exercised or have been afraid of exercising violence at certain moments in their professional practice. Regarding the fact of issuing violence, the interviewees' perception is not only limited to specific moments or conflicts, but also to the reproduction of violence in the care relationship (that is, with the people attended). The comments related to this category are displayed in Table 3.

\section{Table 3}

Comments related to the category characteristics of the violence

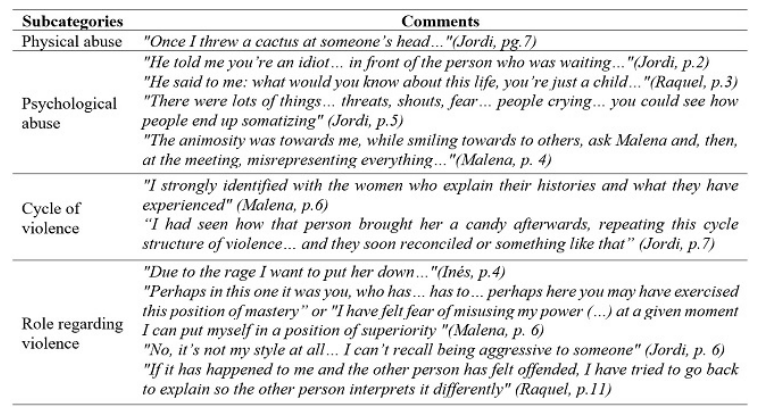

\section{Discussion}

The exploration of the participants' perceptions through semistructured interviews has allowed us, among others, to get closer to their experiences without background theories or other previous research experiences preventing us from understanding what the participants intended to transmit to us in order to answer the questions that we asked them.

These research results indicate that the perception of the violence the interviewees' discourse reveals is strongly determined by personal, contextual, social and organizational factors. Regarding the latter, it is important to underline the characteristics of the economic context and the job market that accepts the organizational practices the interviewed employees recognize as violent practices. According to Caravaca, González-Romero and López (2017), it is important to pay attention to the reduction and precariousness of employment in many countries of the European Union. These authors highlight the deregulation of the job market and the privatization of public services as a result of European austerity policies. These conditions largely coincide with the job characteristics the interviewed employees described in the context of this research. In addition, in a study by López and Seco (2016), an alert is already raised concerning how transformations in the economic field can trigger corporate mobbing strategies. The norms, the policies and the evaluative or organizational framework would be influential factors in the workplace violence studied.

Proceeding with this analysis on the organizational factors involved in the perception of violence, the workers interviewed in this study relate the scarcity of resources and the job insecurity with the conflicts that occur among co-workers and with the institution. Based on their discourse, we can infer that these conditions foster a working climate of competitiveness and struggles for resources and power, a situation that translates into the perception of living in an uncomfortable work environment. These phenomena could be considered as antecedents or behave as a base for the emergence of violence, and not only because they incite it according to the results obtained -, but because they suppose a macro-economic climate that 
is violent for the female and male employees who participated. Background research, such as Cebey and Ferrari (2016), suggests that some of the meanings attributed to workplace violence would be linked to the socio-emotional and cultural environment the work is carried out in. The results of our study tend to corroborate those found in the latter research, as well as those reported in other studies, such as Ansoleaga et al. (2017) in which 70 workers were interviewed, concluding that the work burden, variable remuneration systems, vertical working relations and the prevalence of authoritarian leadership styles would be determining factors of workplace violence. Thus, we reaffirm the importance of what Quiñones, Cantera, and Ojeda already pointed out in 2013, about the existence of a context in which acts of violence are made invisible, a context in which it is not possible to generate actions that permit violence or in which it is not so easy to reveal the aggressions that occur.

Another aspect to highlight are the roles the participants take regarding the violence they perceive in the environment; some of the interviewees only recognize themselves as victims, others as spectators and, finally, some of them also recognize themselves as issuers and receivers of workplace violence. Basically, it refers to the lack of control of negative feelings and problems in emotional management as the triggers of this role ambivalence. Previous studies carried out through interviews and other qualitative methods, such as Baillien et al. (2009) already point out that frustrations can result in fights and disputes in the workplace. Furthermore, the results of our study add other variables, such as interpersonal conflicts or personality characteristics.

On the other hand, the context of this research shows a paradox regarding the production of violence: we can affirm that, according to the interviewees' experience, psychological violence is manifested in various ways (ignoring, blackmailing, blaming, demanding, etc.) in environments where work is being done to eradicate gender violence. A small minority of the interviewees also reports having seen or suffered physical violence (when throwing an object at someone for example). The interviewees' explanation for this fact is related to two phenomena: the first is the personal learning of violence in the social context we live in, i.e. the personal history of violence and its learning. This would mean that, in the participants' own words, the reproduction of violence is generated at the individual level because people learn to solve conflicts or achieve goals through violence and theoretical knowledge is not enough to contain it. On this subject, in a study by Cantera (2004), the alert is already raised that "care centers and teams are social organizations that receive, generate, transmit and reproduce social violence" ( $\mathrm{p}$. 396). These researchresults point in the same direction. The second aspect the interviewees highlighted are the personality characteristics of the people working in these environments, beyond the history of violence or the questioning of violence by each of them. Most studies highlight the characteristics of bullies as being envious or insecure (Parra \& Acosta, 2010) or having academic education problems (Pastrana, 2002). The results reported in this study, however, suggest that interviewees perceive bullies as narcissistic and perverse, characteristics less cited in the literature reviewed. In a study by Cantera and Cantera (2014), some difficulties in the care tasks are proposed because it is not identified how social constructions are framed. In addition, it is stated that this can translate into the inappropriate handling of emotions, self-questioning and pejorative judgments about one's own professionalism or the environment one interacts with. To overcome these difficulties, these authors suggest that it is important to include active self-care in professional training.

Another of the most relevant findings in this study is the participants' manifestation of patterns of violence similar to those suffered by the women treated at the services. The socalled "cycle of violence", which describes the violent dynamics within the partner relationships in which there is gender violence could be reproduced in those environments in which work 
is done to combat this social evil. This model has been widely studied in affective relationships (Walker, 1979), and there is practically no literature that relates it to other environments in which violence occurs.

\section{CONCLUSIONS}

This research was carried out to respond to the study objectives; the first is to identify, describe and analyze the contextual, social, personal and institutional variables that affect the emergence and maintenance of violence in environments where work is being done to eradicate gender violence; the second is to identify, describe and analyze the characteristics of the violence suffered in environments where work is being done to eradicate it. Finally, this research allowed us to answer the proposed objectives, revealing the following conclusions:

- The interviewees state that they have seen, suffered or issued violence, mainly psychological, expressed through actions such as insulting, ignoring, questioning or making invisible the jobs in which they perform their professional work (mainly prevention and intervention in gender violence).

- The analysis of the information the interviewees reported indicates that workplace violence in this environment occurs as a result of mainly personal and organizational factors, which generate serious conflicts among coworkers, superiors and the institution. This research suggests that the phenomenon of workplace violence has a clearly multi-causal nature.

- Professionals who work against gender violence in the Spanish context sometimes do so under precarious working conditions that can lead to the generation of violence or interpersonal conflicts. In addition, our data indicate that these conditions occur in a social and employment scenario perceived as violent in itself. We can conclude that, in an organized, controlled and permitted manner, the current economic and legislative framework creates the background against which these aggressions occur. Likewise, according to the information the interviewed workers reported, the variable female gender aggravates the insecurity of professional performance in this sector.

- According to the results of this study, the aforementioned situation leads to worse mental and physical health for the workers involved. Other consequences also include the deterioration of the quality of care the users of these services receive.

- Finally, the results of this study involve the visualization of the reproduction of violence in environments where work is being done to eradicate it. It is essential to point out this phenomenon and its relationship with the poor working conditions under which some professionals perform their work.

\section{IMPLICATIONS AND LIMITATIONS}

With this study, we intended to deepen people's experiences and perceptions concerning the violence they have been able to see, suffer or issue in their jobs. Basically, because the purpose of this study was neither to quantify nor measure violence, but to discover new approaches, foci or points of departure to proceed with scientific research, this study has revaled interesting phenomena that emerge from the participants' experiences. These findings reveal the main implications of this study, which are detailed below.

First, this research suggests the importance of continuing to investigate the social learning of violent behavior and its relationship with conflict resolution and the management of personal discomfort (as a way to cope with the problem). With increased knowledge of these processes, we can discover the causes that make people set in motion mechanisms and violent strategies to cope with various situations. In addition, the information extracted in this study can help to question the approaches towards prevention and intervention in violence. As observed, theoretical training in violence is very relevant, but insufficient to prevent its emergence. The research participants point out the importance 
of going through a process of experience-based personal questioning to stop the occurrence of this phenomenon.

The conclusions of this study also reveal the need to emphasize not only people in particular, but also the institutional and social practices that allow violence to occur, so that future research could continue to investigate the impact these practices have on the institutions and the workers.

To obtain exhaustive knowledge on this subject, and considering that the approaches in this research are subject to the interviewees' personal perceptions, in future research, this theme could be addressed through other approaches, methods or by formulating hypotheses based on other theoretical frameworks.

The results and conclusions should be taken with due caution, due to the descriptive and exploratory design of the research and the specific characteristics of the environment it was developed in. Although this scenario considerably enriched this investigation, it is nevertheless a very particular context, which is why the conclusions should be considered in due proportion.

\section{Acknowledgements}

The authors want to thank to the participants of this study. This paper has been carried out within the $\mathrm{PhD}$ Program "People and society in the contemporary world" of the Universitat Autònoma de Barcelona.

\section{References}

Acinas, M. P. (2012). Burn-out y desgaste por empatía en profesionales de cuidados paliativos. Revista Digital de Medicina Psicosomática y Psicoterapia, 2(4), 1-22. Retrieved from http://www.psicociencias.com/pdf_no ticias/Burnout_en_cuidados_paliativos.pdf

Acosta, M., Aguilera, M., \& Pozos, B. (2009). Relación entre el acoso moral en el trabajo y el estilo interpersonal en el manejo de conflictos. Ciencia y Trabajo, 21, 14-17. Retrieved from https://dialnet.unirioja.es/s ervlet/articulo?codigo $=3219068$

Aguilar, S., \& Barroso, O. (2015). La triangulación de datos como estrategia en investigación educativa. Pixel-Bit Revista de Medio de Educación, 47, 73-88. Retrieved from http://www.redalyc.org/pdf/368/3684 1180005.pdf

Ansoleaga, E., Díaz, X., Mauro, A., \& Toro, J. P. (2017). Dimensiones organizacionales de la violencia en el trabajo en Chile. Considerando diferencias ocupacionales y de género. Estudio en tres sectores económicos (Final report). Santiago de Chile: Fondo Nacional de Desarrollo Científico y Tecnológico. Retrieved from http://www.ce $\mathrm{m} . \mathrm{cl} / \mathrm{publica} /$ dovt.pdf

Arón, A. M., \& Llanos, M. T. (2004). Cuidar los que cuidan: desgaste profesional y cuidado de los equipos que trabajan con violencia. Sistemas Familiares, 1(2), 5-15. Retrieved from http://localhost:80/jspui/handle/1072 0/259

Baillien, E., Neyens, I., De Witte, H., \& De Cuyper, N. (2009). A qualitative study on the development of workplace bullying: Towards a three way model. Journal of Community and Applied Social Psychology, 19(1), 1-16. https://doi.org/10.1002/casp.9 77

Bernad, M. J., Pérez, J., Díaz, E., García, C., \& Villagrasa, V. (2013). Cuidado y autocuidado de los profesionales de intervención directa. Aragón: Colegio Oficial de Psicólogos de Aragón. Retrieved from https://es.scribd.com/document/2700 76039/Cuidado-y-Autocuidado-de-Los-Pr ofesionales-de-Intervencion-Directa-2

California, Department of Industrial Relations, Division of Occupational Safety and Health. (1995). Guidelines for workplace security [on line]. San Francisco: Author. Retrieved from https://www.dir.ca.gov/dos h/dosh_publications/worksecurity.html

Campoy, T., \& Gomes, E. (2015). Técnicas e instrumentos cualitativos de recogida 
de datos. In A. Pantoja Vallejo (Coord.), Manual básico para la realización de tesinas, tesis y trabajos de investigación (2.a ed., pp. 273-300). Madrid: Editorial EOS.

Cantera Espinosa, L. (1999). Te pego porque te quiero. La violencia en la pareja. Barcelona: UAB.

Cantera Espinosa, L. (2004). Más allá del género. Nuevos enfoques de "nuevas" dimensiones y direcciones de la violencia en la pareja (Doctoral dissertation). Universidad Autónoma de Barcelona. Retrieved from http://www.tdx.cat/bitstream/handle/ 10803/5441/lce1de1.pdf? sequence $=1$

Cantera, L. M., \& Cantera, F. M. (2014). El auto-cuidado activo y su importancia para la psicología comunitaria. Psicoperspectivas: Individuo y Sociedad, 13(2), 88-97. https://doi.org/10.5027/Psico perspectivas-vol13-issue2-fulltext-406

Cantera, L., Pallarès, S., \& Selva, C. (2013). Violencia. In L. Cantera, S. Pallarès \& C. Selva (Eds.), Del malestar al bienestar laboral (pp.77-105). Barcelona: Amentia Editorial.

Caravaca, I., González-Romero, G., \& López, P. (2017). Crisis y empleo en las ciudades españolas. EURE: Revista Latinoamericana de Estudios Urbano Regionales, 43(128), 31-54. Retrieved from http://www.scielo.cl/ pdf/eure/v43n128/art02.pdf

Cebey, M. C., \& Ferrari, L. E. (november, 2016). Significaciones atribuidas a la violencia laboral. Paper presented at VIII Congreso Internacional de Investigación y Práctica Profesional en Psicología. Buenos Aires: Universidad de Buenos Aires.

European Foundation for the Improvement of Living and Working Conditions. (2000). Third European survey on working conditions 2000 (Report). Retrieved from http://www.eurofound.eu.int/publicat ions/files/EF0121EN.pdf

López, M., \& Seco, E. (2016). Tipologia de Mobbing - una mirada desde la responsabilidad de la empresa. Sociologias, 18(43), 364-401. https://doi.org/10.1590/1 5174522-018004321
Morrow, L., \& Smith, L. (2000). Qualitative research for counseling psychology. In S. D. Brown \& R. W. Lent (Eds.), Handbook of counseling psychology (3rd ed., pp. 199-230). New York: John Wiley \& Sons.

Pando, M., Aranda, C., Salazar, J., \& Torres, M. (2016). Prevalencia de violencia psicológica y acoso laboral en trabajadores de Iberoamérica. Enseñanza e Investigación en Psicología, 21(1), 39-45. Retrieved from http://www.redalyc.org/articulo.oa?id $=29248180004$

Parra, L., \& Acosta, M. (2010). La investigación cuantitativa del acoso psicológico laboral en los sectores de la educación superior y de la salud. Una revisión sistemática. Entramado, 6(1), 158-172. Retrieved from http://www.redalyc.org/articulo.oa?id $=265419646010$

Pastrana, J. (2002). ¿Cuánto cuesta el mobbing en España? Lan Harremanak. Revista de Relaciones Laborales, 7(2), 171-181. Recuperado de https://dialnet.unirioja.es/se rvlet/articulo?codigo $=640375$

Quintana Peña, A. (2006). Metodología de investigación científica cualitativa. In A. Quintana Peña \& W. Montgomery (Eds.), Psicología: tópicos de actualidad (pp. 47-84). Lima: Universidad Nacional Mayor de San Marcos.

Quiñones, P., Cantera, L. M., \& Ojeda, C. L. (2013). La violencia relacional en contextos laborales que trabajan contra la violencia. In L. Cantera, S. Pallarès \& C. Selva (Eds.), Del malestar al bienestar laboral (pp.135-155). Barcelona: Amentia Editorial.

Relinque, S., Moral-Arroyo, G., \& GonzálezFernández, T. (2013). Consejos prácticos para escribir un artículo cualitativo publicable en psicología. Psychosocial Intervention, 22(1), 71-79. https://doi.org/1 $0.5093 /$ in 2013 a 9

Román, J. (2017). La patologización del acosado laboral. Psicología y Salud, 27(537), 269-278. Retrieved from http://revistas.uv.mx/index.php/psicys alud/article/viewFile/2665/4689 
Sanmartín, J. (2007). ¿Qué es la violencia? Una aproximación al concepto y a la clasificación de la violencia. Daimon. Revista de Filosofía, 42, 9-22. Retrieved from https://revistas.um.es/daimon/article/ view/95881

Sanmartín, J. (2012). Claves para entender la violencia en el siglo XXI. Ludus Vitalis, 20(38), 145-160. Retrieved from http://www.ludus-vitalis.org/ojs/index .php/ludus/article/view/85

San Martín, D. (2014). Teoría fundamentada y Atlas-ti: recursos metodológicos para la investigación educativa. Revista Electrónica de Investigación Educativa, 16(1), 104-122. Retrieved from http://atlasti.com/wp-conte nt/uploads/2014/05/San-Martin-2014.pdf

Strauss, A., \& Corbin, J. (1998). Basics of qualitative research. Techniques and procedures for developing grounded theory. New York: Sage.

Topa, G., Depolo, M., \& Morales, J. F. (2007). Acoso laboral: meta-análisis y modelo integrador de sus antecedentes y consecuencias. Psicothema, 19(1), 88-94. ht tps://doi.org/10.5944/educxx1.17.1.10708

Toro, J. P., \& Gómez-Rubio, C. (2016). Factores facilitadores de la violencia laboral: una revisión de la evidencia científica en América Latina. Ciencia $\mathcal{E}$ Trabajo, 18(56), 110-116. https://doi.org/10.4067/S0718-24 492016000200006

Walker, L. E. (1979). The battered woman. New York: Harper \& Row.

\section{Notes}

* Research article. 